\title{
VIBRATIONAL STUDIES OF THE DISULFIDE GROUP IN PROTEINS
}

\section{Part III. A simplified ab initio force field for diethyl disulfide and SS and CS stretch frequency-conformation correlations for diisobutyl disulfide}

\author{
WENYUN ZHAO*, JAGDEESH BANDEKAR and SAMUEL KRIMM \\ Biophysics Research Diviston and Department of Physics, University of Michigan, Ann Arbor, \\ MI 48109 (USA)
}

(Recelved 21 November 1989)

\begin{abstract}
We have obtained a simplified ab initıo force field for diethyl disulfide, based on our previous scaled ab initio force field, which can be used in normal coordinate analysis of proteins containing the disulfide bridge A normal coordınate analysıs has been performed for dusobutyl disulfide in all possible conformations The correlations thus obtained between the SS and CS stretch frequencies and the conformation are useful in understanding similar correlations in proteins containıng the disulfide bridge A simple way is presented to identify local $C_{2}$ symmetry in a disulfide bridge through Raman polarization studies
\end{abstract}

\section{INTRODUCTION}

The dependence of the SS stretch ( $\nu(\mathrm{SS}))$ and CS stretch $(\nu(\mathrm{CS}))$ frequencies on the conformation of the disulfide bridge in proteins, $\mathrm{H}-\mathrm{C}-\mathrm{CH}_{2}-\mathrm{S}-\mathrm{S}-\mathrm{CH}_{2}-\mathrm{C}-\mathrm{H}$, has been the subject of several papers [1-6] Since Van Wart and Scheraga [7] agreed with the assignments of Sugeta et al. [2], the controversial aspects of this subject seem to have been resolved. These correlations propose that $\nu$ (SS) lies at about 510,525 or $540 \mathrm{~cm}^{-1}$ when the conformation contains two, one, or no $\mathrm{H}$ atoms, respectively, trans to distal $\mathrm{S}$ atoms across the CS bond, while $\nu$ (CS) lies at $630-670$ or $700-745 \mathrm{~cm}^{-1}$ when the conformation contains an $\mathrm{H}$ or a $\mathrm{C}$ atom, respectively, trans to the $\mathrm{S}$ atom across the CC bond [2] These simple rules indicate that $\nu$ (SS) depends on $\tau(\mathrm{CS})$, the CCSS dihedral angle, and $\nu(\mathrm{CS})$ depends on $\tau(\mathrm{CC})$, the HCCS

*Present address Department of Chemical Engıneerıng, Beyıng Institute of Chemical Technology, Beljıng 10013, Chına 
dihedral angle However, the rules do not indicate if there is any correlation between $\nu(\mathrm{SS})$ and $\tau(\mathrm{CC})$ or between $\nu(\mathrm{CS})$ and $\tau(\mathrm{CS})$ Our previous study [8] showed that the latter dependence exists in diethyl disulfide, $\mathrm{C}_{2} \mathrm{H}_{5} \mathrm{SSC}_{2} \mathrm{H}_{5}$, and thus a more detalled description of these correlations is necessary than had been indicated previously [2]

To investigate such correlations in a protein would require normal mode analysis on a peptide structure containing the disulfide bridge together with a force field that includes a reliable conformation dependence of the force constants In the latter respect, the scaled ab initio force field that was reported previously $[8,9]$ has proved to be much better than empirical force fields [ 6 , 10] However, this force field, when transferred to other molecules, would require more than 1000 force constants for every conformation, which would be unwieldy We have therefore obtained a simplified force constant set based on the scaled ab initio force field

Even with a reliable simple force field, the systematic investigation of the vibrational modes of the disulfide bridge in proteins is very complicated For example, we have found from our calculation that $\nu$ (SS) and $\nu$ (CS) depend not only on $\tau(\mathrm{SS})$ and the two $\tau(\mathrm{CS})$, but also on the two $\chi^{\prime}$, two $\phi$, two $\psi$ and four $\omega$ dihedral angles of the peptide groups around the disulfide bridge The variation of any one of these angles may lead to about a $10 \mathrm{~cm}^{-1}$ change in $\nu$ (SS) or $\nu$ (CS) A simplified model calculation to obtain a general understanding of this subject seemed useful, and we have therefore analyzed the conformational dependence of the normal modes of dissobutyl disulfide, $\left(\mathrm{CH}_{3}\right)_{2} \mathrm{CHCH}_{2} \mathrm{SSCH}_{2} \mathrm{CH}\left(\mathrm{CH}_{3}\right)_{2}$

\section{SIMPLIFIED SCALED AB INITIO FORCE FIELD FOR DIETHYL DISULFIDE}

As explained in our previous paper [8], for any one of six symmetric conformations, CGC, GGG, SGS, TGT, $\mathrm{S}^{\prime} \mathrm{GS}^{\prime}$ and $\mathrm{G}^{\prime} \mathrm{GG}^{\prime}$ of $\mathrm{C}_{2} \mathrm{H}_{5} \mathrm{SSC}_{2} \mathrm{C}_{5}(\mathrm{C}=c \iota s$, $\mathrm{G}=$ gauche, $\mathrm{S}=$ skew, $\mathrm{T}=$ trans $)$, a complete force constant matrix containıng about 1080 elements $\left(F_{l \jmath}\right.$ and $F_{\jmath l}$ are counted once) has been obtained by scaling the ab initio force field to fit the observed frequencies In order to simplify this force field, it is necessary to eliminate those force constants that are less important in the normal coordinate calculation. The vibrational eigenvalue $\lambda_{t}$ is determined by

$\lambda_{\imath}=\sum_{j k} L_{j l} L_{k l} F_{j k}$

Lettıng $F_{j k}$ be zero would affect $\lambda_{\iota}$ by a relative difference $2 L_{j l} L_{k l} F_{j k} / \lambda_{l}$, which is the potential energy distribution (PED) contribution to the $\iota$ th normal vibration from this force constant, $F_{j k}$ Therefore, a simple criterion can be used if 


$$
\sum_{\imath}\left(\mathrm{L}_{j l} \mathrm{~L}_{k l} \mathrm{~F}_{j k} / \lambda_{\imath}\right)^{2}<\mathrm{C}
$$

where $C$ is a given constant, $F_{j k}$ is considered to be negligible and is deleted from the force constant set

It was found that the number of force constants could be considerably reduced if the $\mathbf{F}$ matrix in internal coordinates was transformed into the $\mathbf{F}_{\mathrm{s}}$ matrix in symmetry coordinates and the same criterion applied. Therefore, symmetry coordinates were used in the $\mathrm{CH}_{2}$ group in the subsequent calculations However, internal coordinates were retained in the $\mathrm{CH}_{3}$ group so that these could be easily combined with the peptide force field, where $C_{3 \mathrm{v}}$ symmetry no longer exists The internal coordınates and symmetry coordinates are shown in Fig 1 and Table 1

'The value of $C$ was selected to be 0001 , which resulted in only five of 252 frequencies of the six symmetric conformers having errors of $0.6-07 \%$, with none exceeding $07 \%$, when this simplified force field was compared with the original complete scaled ab initio force field The maximum error for $\nu$ (SS) and $\nu(\mathrm{CS})$ was $19 \mathrm{~cm}^{-1}$ Only $20-25 \%$ of the force constants remained when $C$ was set at 0001 Increasing this value gives rise to larger errors and decreas-
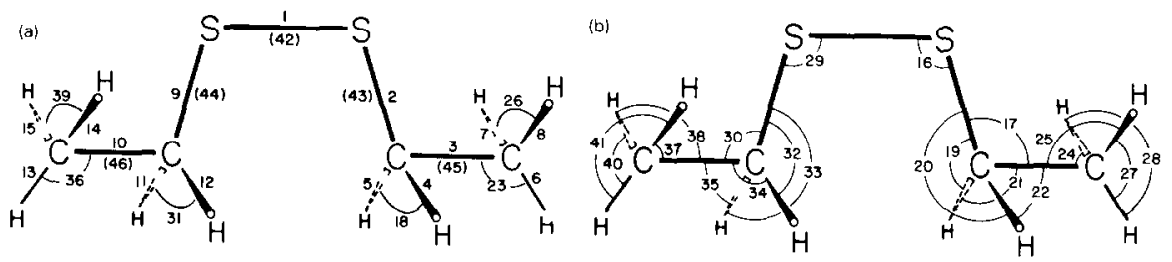

$\mathrm{F}_{1 g} 1$ Numberıng of internal coordınates for $\mathrm{C}_{2} \mathrm{H}_{5} \mathrm{SSC}_{2} \mathrm{H}_{5}$

\section{'IABLE 1}

Symmetry coordinates for $\mathrm{C}_{2} \mathrm{H}_{5} \mathrm{SSC}_{2} \mathrm{H}_{5}{ }^{a}$

$$
\begin{aligned}
& S_{17}=5 R_{17}-R_{18}-R_{19}-R_{20}-R_{21}-R_{22} \\
& S_{18}=4 R_{18}-R_{19}-R_{20}-R_{21}-R_{22} \\
& S_{19}=R_{19}-R_{20}+R_{21}-R_{22} \\
& S_{20}=R_{19}+R_{20}-R_{21}-R_{22} \\
& S_{21}=R_{19}-R_{20}-R_{21}+R_{22} \\
& S_{22}=R_{17}+R_{18}+R_{19}+R_{20}+R_{21}+R_{22} \\
& S_{30}=5 R_{30}-R_{31}-R_{32}-R_{33}-R_{34}-R_{35} \\
& S_{31}=4 R_{31}-R_{32}-R_{33}-R_{34}-R_{35} \\
& S_{32}=R_{32}-R_{33}+R_{34}-R_{35} \\
& S_{33}=R_{32}+R_{33}-R_{34}-R_{35} \\
& S_{34}=R_{32}-R_{33}-R_{34}+R_{35} \\
& S_{35}=R_{30}+R_{31}+R_{32}+R_{33}+R_{34}+R_{35}
\end{aligned}
$$

${ }^{a}$ All other symmetry coordinates have the same number as the internal coordinates 
TABLE 2

Force constants for $\mathrm{C}_{2} \mathrm{H}_{5} \mathrm{SSC}_{2} \mathrm{H}_{5}{ }^{2}$

(a) Conformer-independent force constant

\begin{tabular}{|c|c|c|c|c|c|}
\hline Coordınate $^{b}$ & Number & Value & Coordinate $^{b}$ & Number & Value \\
\hline $\mathrm{CHs}$ & $(4,4)(5,5)$ & 4805 & $\mathrm{CH}_{2} \mathrm{tw} / \mathrm{CCH} \mathrm{b}$ & $(21,24)$ & 0067 \\
\hline $\mathrm{CH} s$ & $(6,6)$ & 4738 & $\mathrm{CH}_{2} \mathrm{tw} / \mathrm{CCH} \mathrm{b}$ & $(21,25)$ & -0067 \\
\hline $\mathrm{CH} \mathrm{s}$ & $(7,7)(8,8)$ & 4812 & $\mathrm{CH}_{2} \mathrm{tw} / \mathrm{CH}_{2} \mathrm{tw}$ & $(21,34)$ & 0002 \\
\hline $\mathrm{CH} \mathrm{s} / \mathrm{CH} \mathrm{s}$ & $\begin{array}{l}(4,5)(6,7) \\
(6,8)(7,8)\end{array}$ & 0048 & $\mathrm{CCH} \mathrm{b/CCH} \mathrm{b}$ & $\begin{array}{l}(23,24)(23,25) \\
(24,25)\end{array}$ & -0131 \\
\hline $\mathrm{CH} \mathrm{s} / \mathrm{CH}_{2} \mathrm{~d}$ & $(4,18)(5,18)$ & 0089 & $\mathrm{CCH} \mathrm{b} / \mathrm{HCH} \mathrm{b}$ & $(23,26)$ & -0097 \\
\hline $\mathrm{CC} \mathrm{s} / \mathrm{HCH} \mathrm{b}$ & $(3,26)$ & -0141 & $\mathrm{CCH} \mathbf{b} / \mathrm{HCH} \mathbf{b}$ & $(23,27)(23,28)$ & -0086 \\
\hline $\mathrm{CC} \mathrm{s} / \mathrm{HCH} \mathrm{b}$ & $(3,27)$ & -0150 & $\mathrm{CCH} \mathbf{b} / \mathbf{H C H} \mathbf{b}$ & $(24,26)(25,26)$ & -0092 \\
\hline $\mathrm{SSC} \mathrm{b} / \mathrm{CH}_{2} \mathrm{r}$ & $(16,32)$ & 0007 & $\mathrm{CCH} \mathrm{b/HCH} \mathrm{b}$ & $(24,27)(25,28)$ & -0099 \\
\hline $\mathrm{CH}_{2} \mathrm{r} / \mathrm{CCH} \mathrm{b}$ & $(19,24)$ & -0059 & $\mathrm{CCH}$ b/HCH b & $(24,28)(25,27)$ & -0096 \\
\hline $\mathrm{CH}_{z} \mathrm{w} / \mathrm{CCH} b$ & $(20,23)$ & 0031 & $\mathrm{CCH} b$ & $(25,25)$ & 0539 \\
\hline $\mathrm{CH}_{2} \mathrm{w} / \mathrm{CCH} b$ & $(20,24)(20,25)$ & -0028 & $\mathrm{HCH} \mathbf{b}$ & $(26,26)$ & 0447 \\
\hline $\mathrm{CH}_{2} \mathrm{w} / \mathrm{HCH} \mathrm{b}$ & $(20,26)$ & 0012 & $\mathrm{HCH} \mathbf{b}$ & $(27,27)(28,28)$ & 0450 \\
\hline $\mathrm{CH}_{2} \mathrm{w} / \mathrm{CH}_{2} \mathrm{w}$ & $(20,33)$ & 0003 & $\begin{array}{l}\mathrm{HCH} \text { b/HCH b } \\
\mathrm{HCH} \mathrm{b} / \mathrm{HCH} \text { b }\end{array}$ & $\begin{array}{l}(26,27)(26,28) \\
(27,28)\end{array}$ & $\begin{array}{l}-0081 \\
-0077\end{array}$ \\
\hline
\end{tabular}

(b) Conformer-dependent force constants

\begin{tabular}{|c|c|c|c|c|c|c|c|}
\hline \multirow[t]{2}{*}{ Coordınate $^{\mathrm{b}}$} & \multirow[t]{2}{*}{ Number } & \multicolumn{6}{|l|}{ Value } \\
\hline & & CGC & GGG & SGS & TGT & $\mathrm{S}^{\prime} \mathrm{GS}^{\prime}$ & $\mathrm{G}^{\prime} \mathrm{GG}^{\prime}$ \\
\hline SS s & $(1,1)$ & 2610 & 2636 & 2626 & 2650 & 2622 & 2541 \\
\hline $\mathrm{SS} / \mathrm{SC} \mathrm{s}$ & $(1,2)$ & 0122 & 0095 & 0092 & 0075 & 0096 & 0110 \\
\hline $\mathrm{SS} \mathrm{s} / \mathrm{SSC} b$ & $(1,16)$ & 0202 & 0256 & 0253 & 0242 & 0254 & 0255 \\
\hline $\mathrm{SS} \mathrm{s} / \mathrm{SCC} \mathrm{d}$ & $(1,17)$ & 0000 & -0020 & 0011 & 0068 & 0024 & 0041 \\
\hline $\mathrm{SS} \mathrm{s} / \mathrm{CH}_{2} \mathbf{r}$ & $(1,19)$ & 0015 & -0036 & -0015 & -0003 & 0008 & 0038 \\
\hline $\mathrm{SCs}$ & $(2,2)$ & 2746 & 2852 & 2780 & 2841 & 2781 & 2837 \\
\hline $\mathrm{sC} \mathrm{s} / \mathrm{CC} \mathrm{s}$ & $(2,3)$ & 0185 & 0197 & 0185 & 0180 & 0185 & 0161 \\
\hline $\mathrm{sCs} / \mathrm{CS} \mathrm{s}$ & $(2,9)$ & 0022 & 0015 & 0016 & 0017 & 0017 & 0048 \\
\hline $\mathrm{SC}$ s/SSC b & $(2,16)$ & 0368 & 0165 & 0187 & 0093 & 0186 & 0183 \\
\hline $\mathrm{SC} \mathrm{s} / \mathrm{SCC} \mathrm{d}$ & $(2,17)$ & 0408 & 0294 & 0204 & 0125 & 0192 & 0302 \\
\hline $\mathrm{SC} \mathrm{s} / \mathrm{CH}_{2} \mathrm{~d}$ & $(2,18)$ & -0135 & -0143 & -0146 & -0139 & -0148 & -0150 \\
\hline $\mathrm{SC} \mathrm{s} / \mathrm{CH}_{2} \mathrm{r}$ & $(2,19)$ & -0025 & 0092 & 0025 & 0007 & -0021 & -0091 \\
\hline $\mathrm{SC} \mathrm{s} / \mathrm{CH}_{2} \mathrm{w}$ & $(2,20)$ & 0346 & 0311 & 0349 & 0368 & 0352 & 0323 \\
\hline $\mathrm{SC} \mathrm{s} / \mathrm{CCH} b$ & $(2,23)$ & 0024 & 0057 & 0052 & 0028 & 0048 & 0053 \\
\hline $\mathrm{SC} \mathrm{s} / \mathrm{SC} \mathrm{t}$ & $(2,43)$ & 0002 & 0032 & -0003 & 0000 & 0005 & -0022 \\
\hline $\mathrm{CCs}$ & $(3,3)$ & 4139 & 4153 & 4113 & 4074 & 4099 & 4174 \\
\hline $\mathrm{CC} \mathrm{s} / \mathrm{SSC} b$ & $(3,16)$ & -0013 & -0021 & 0028 & 0069 & 0042 & -0061 \\
\hline $\mathrm{CC} \mathrm{s} / \mathrm{SCC} \mathrm{d}$ & $(3,17)$ & 0128 & 0162 & 0154 & 0194 & 0154 & 0083 \\
\hline $\mathrm{CCs} / \mathrm{CH}_{2} \mathrm{~d}$ & $(3,18)$ & -0110 & -0114 & -0122 & -0122 & -0122 & -0115 \\
\hline $\mathrm{CC} \mathrm{s} / \mathrm{CH}_{2} \mathrm{w}$ & $(3,20)$ & -0284 & -0269 & -0272 & -0279 & -0271 & -0274 \\
\hline $\mathrm{CCs} / \mathrm{CCH} b$ & $(3,23)$ & 0128 & 0102 & 0099 & 0125 & 0101 & 0111 \\
\hline $\mathrm{CC}$ s/CCH b & $(3,24)$ & 0150 & 0161 & 0166 & 0151 & 0158 & 0158 \\
\hline $\mathrm{CC} \mathrm{s} / \mathrm{CCH} \mathrm{b}$ & $(3,25)$ & 0158 & 0165 & 0159 & 0149 & 0162 & 0150 \\
\hline $\mathrm{CC} \mathrm{s} / \mathrm{HCH} b$ & $(3,28)$ & -0151 & -0156 & -0144 & -0150 & -0153 & -0142 \\
\hline
\end{tabular}


(b) Conformer-dependent force constants

\begin{tabular}{|c|c|c|c|c|c|c|c|}
\hline \multirow[t]{2}{*}{ Coordınate ${ }^{\mathrm{b}}$} & \multirow[t]{2}{*}{ Number } & \multicolumn{6}{|l|}{ Value } \\
\hline & & CGC & GGG & SGS & TGT & $S^{\prime} G S^{\prime}$ & $\mathrm{G}^{\prime} \mathrm{GG}^{\prime}$ \\
\hline $\mathrm{SSC} \mathrm{b}$ & $(16,16)$ & 1517 & 1205 & 1212 & 1082 & 1214 & 1221 \\
\hline $\mathrm{SSC} b / \mathrm{SCC} d$ & $(16,17)$ & 0286 & 0005 & 0068 & 0215 & 0090 & 0077 \\
\hline $\mathrm{SSC} \mathrm{b} / \mathrm{CH}_{2} \mathbf{r}$ & $(16,19)$ & 0000 & -0067 & -0062 & 0000 & 0048 & 0071 \\
\hline $\mathrm{SSC} \mathrm{b/ \textrm {CH } _ { 2 } \mathrm { w }}$ & $(16,20)$ & 0083 & 0058 & 0018 & -0058 & 0007 & 0060 \\
\hline $\mathrm{SSC} \mathrm{b} / \mathrm{CH}_{2}$ tw & $(16,21)$ & 0008 & -0131 & -0076 & -0011 & 0074 & 0119 \\
\hline $\mathrm{SSC} \mathrm{b} / \mathrm{CCH} \mathrm{b}$ & $(16,23)$ & -0072 & -0019 & 0016 & 0036 & 0018 & -0026 \\
\hline $\mathrm{SSC} b / \mathrm{CSS} b$ & $(16,29)$ & -0005 & -0049 & -0030 & -0030 & -0033 & 0181 \\
\hline $\mathrm{SSC} b / \mathrm{CCS} d$ & $(16,30)$ & 0027 & 0014 & 0033 & -0003 & -0023 & 0116 \\
\hline $\mathrm{SSC} b / \mathrm{SS} t$ & $(16,42)$ & 0120 & 0024 & 0007 & 0018 & 0014 & 0304 \\
\hline $\mathrm{SSC} b / \mathrm{SC} t$ & $(16,43)$ & 0003 & 0067 & -0012 & 0008 & -0003 & -0050 \\
\hline $\mathrm{SSC} \mathbf{b} / \mathrm{CS} t$ & $(16,44)$ & 0050 & 0014 & -0014 & 0022 & -0021 & 0008 \\
\hline $\mathrm{SSC} \mathrm{b} / \mathrm{CH}_{3} \mathrm{t}$ & $(16,45)$ & 0038 & 0003 & 0009 & 0001 & -0010 & 0013 \\
\hline $\mathrm{SSC} b / \mathrm{CH}_{3} \mathrm{t}$ & $(16,46)$ & -0001 & -0001 & 0001 & -0003 & 0002 & 0005 \\
\hline $\mathrm{SSC} d$ & $(17,17)$ & 1094 & 0909 & 0860 & 0835 & 0852 & 0952 \\
\hline $\mathrm{SCC} \mathrm{d} / \mathrm{CH}_{2} \mathrm{r}$ & $(17,19)$ & -0004 & 0047 & 0023 & 0001 & -0030 & -0042 \\
\hline $\mathrm{SCC} \mathrm{d} / \mathrm{CH}_{2} \mathrm{w}$ & $(17,20)$ & 0040 & 0034 & 0026 & 0020 & 0027 & 0037 \\
\hline $\mathrm{SCC} d / \mathrm{CCH} b$ & $(17,23)$ & 0056 & 0096 & 0101 & 0094 & 0100 & 0092 \\
\hline $\mathrm{SCC} d / \mathrm{CCH} b$ & $(17,24)$ & -0016 & -0033 & -0045 & -0035 & -0040 & -0043 \\
\hline $\mathrm{SCC} \mathrm{d} / \mathrm{CCH} b$ & $(17,25)$ & -0005 & -0046 & -0041 & -0036 & -0043 & -0042 \\
\hline $\operatorname{sCC} d / \operatorname{CCS} d$ & $(17,30)$ & 0040 & 0001 & 0009 & 0004 & 0001 & 0142 \\
\hline $\mathrm{SCC} d / \mathrm{SS} \mathrm{t}$ & $(17,42)$ & 0098 & 0016 & 0020 & 0005 & -0015 & 0213 \\
\hline $\mathrm{SCC} d / \mathrm{SC} t$ & $(17,43)$ & 0039 & 0066 & 0061 & 0003 & -0075 & -0043 \\
\hline $\mathrm{SCC} \mathrm{d} / \mathrm{CH}_{3} \mathrm{t}$ & $(17,45)$ & 0021 & 0003 & -0012 & -0001 & 0014 & 0006 \\
\hline $\mathrm{CH}_{2} \mathrm{~d}$ & $(18,18)$ & 0563 & 0539 & 0533 & 0533 & 0536 & 0545 \\
\hline $\mathrm{CH}_{2} \mathrm{~d} / \mathrm{CH}_{2} \mathrm{w}$ & $(18,20)$ & -0009 & -0012 & -0001 & 0000 & -0002 & -0016 \\
\hline $\mathrm{CH}_{2} \mathrm{r}$ & $(19,19)$ & 0759 & 0717 & 0674 & 0660 & 0678 & 0722 \\
\hline $\mathrm{CH}_{2} \mathrm{r} / \mathrm{CH}_{2} \mathrm{tw}$ & $(19,21)$ & -0013 & -0027 & -0021 & -0020 & -0021 & -0017 \\
\hline $\mathrm{CH}_{9} \mathrm{r} / \mathrm{CCH}$ b & $(19,25)$ & 0051 & 0060 & 0060 & 0061 & 0063 & 0064 \\
\hline $\mathrm{CH}_{2} \mathrm{r} / \mathrm{CH}_{2} \mathrm{r}$ & $(19,32)$ & 0032 & 0001 & -0001 & 0001 & 0004 & -0002 \\
\hline $\mathrm{CH}_{2} \mathrm{r} / \mathrm{SS} \mathrm{t}$ & $(19,42)$ & 0084 & 0000 & 0007 & 0012 & 0002 & -0023 \\
\hline $\mathrm{CH}_{2} \mathrm{r} / \mathrm{SC} \mathrm{t}$ & $(19,43)$ & -0062 & 0065 & 0019 & -0002 & 0014 & 0025 \\
\hline $\mathrm{CH}_{2} \mathrm{r} / \mathrm{CH}_{3} \mathrm{t}$ & $(19,45)$ & -0027 & -0017 & -0015 & -0015 & -0014 & -0016 \\
\hline $\mathrm{CH}_{2} \mathrm{w}$ & $(20,20)$ & 0590 & 0595 & 0610 & 0618 & 0607 & 0594 \\
\hline $\mathrm{CH}_{2} \mathrm{w} / \mathrm{CH}_{2} \mathrm{tw}$ & $(20,21)$ & -0003 & -0004 & -0004 & -0002 & 0008 & 0003 \\
\hline $\mathrm{CH}_{2} \mathrm{w} / \mathrm{SS} \mathrm{t}$ & $(20,42)$ & 0009 & 0000 & 0001 & 0006 & 0011 & 0013 \\
\hline $\mathrm{CH}_{2} \mathrm{w} / \mathrm{SC} \mathrm{t}$ & $(20,43)$ & -0007 & -0004 & -0020 & -0001 & 0026 & 0000 \\
\hline $\mathrm{CH}_{2}$ tw & $(21,21)$ & 0589 & 0585 & 0589 & 0598 & 0588 & 0588 \\
\hline $\mathrm{CH}_{2} \mathrm{tw} / \mathrm{SC} \mathrm{t}$ & $(21,43)$ & -0059 & 0005 & 0031 & -0018 & 0014 & 0001 \\
\hline $\mathrm{CCH} \mathrm{b}$ & $(23,23)$ & 0533 & 0525 & 0522 & 0521 & 0521 & 0527 \\
\hline $\mathrm{CCH} \mathrm{b}$ & $(24,24)$ & 0531 & 0544 & 0540 & 0540 & 0541 & 0536 \\
\hline $\operatorname{SSt}$ & $(42,4$ & 0490 & 0154 & 0151 & 0152 & 0144 & 0469 \\
\hline $\mathrm{SS} \mathrm{t} / \mathrm{SC} \mathrm{t}$ & $(42,43)$ & 0151 & -0001 & 0004 & -0001 & -0002 & -0021 \\
\hline $\mathrm{SS} \mathrm{t} / \mathrm{CH}_{3} \mathrm{t}$ & $(42,45)$ & -0022 & 0007 & 0000 & -0002 & -0001 & 0040 \\
\hline $\mathrm{SCt}$ & $(43,43)$ & -0005 & 0113 & -0053 & 0059 & -0049 & 0085 \\
\hline $\mathrm{SC} t / \mathrm{CSt}$ & $(43,44)$ & 0062 & 0000 & -0001 & -0002 & -0006 & 0007 \\
\hline $\mathrm{SC} \mathrm{t} / \mathrm{CH}_{3} \mathrm{t}$ & $(43,45)$ & -0005 & 0003 & 0002 & -0008 & 0000 & 0026 \\
\hline $\mathrm{CH}_{3} \mathrm{t}$ & $(45,45)$ & 0098 & 0096 & 0092 & 0081 & 0090 & 0114 \\
\hline
\end{tabular}


TABLE 2 (continued)

(c) Special force constants

\begin{tabular}{|c|c|c|c|c|c|}
\hline \multicolumn{3}{|c|}{ CGC conformer only } & \multicolumn{3}{|c|}{$\mathrm{G}^{\prime} \mathrm{GG}^{\prime}$ conformer only } \\
\hline Coordinate ${ }^{\mathrm{b}}$ & Number & Value & Coordınate ${ }^{b}$ & Number & Value \\
\hline $\mathrm{SC} \mathrm{s} / \mathrm{CCS} \mathrm{d}$ & $(2,30)$ & 0023 & $\mathrm{SC} \mathrm{s} / \mathrm{CH}_{2} \mathrm{tw}$ & $(2,21)$ & -0039 \\
\hline $\mathrm{SC} \mathrm{s} / \mathrm{SS} \mathrm{t}$ & $(2,42)$ & 0066 & $\mathrm{SC} s / \mathrm{CSS} b$ & $(2,29)$ & 0090 \\
\hline $\mathrm{CHs} / \mathrm{SS} \mathrm{t}$ & $(7,42)$ & -0074 & $\mathrm{SC} \mathrm{s} / \mathrm{CCS} \mathrm{d}$ & $(2,30)$ & 0074 \\
\hline $\mathrm{SSC} \mathrm{b/CH} \mathrm{CH}_{2}$ & $(16,18)$ & -0044 & $\mathrm{SC} / \mathrm{SSt}$ & $(2,42)$ & 0122 \\
\hline $\mathrm{SSC} \mathrm{b} / \mathrm{CCH} b$ & $(16,25)$ & 0041 & $\mathrm{SCC} \mathrm{d} / \mathrm{CH}_{2} \mathrm{r}$ & $(17,32)$ & -0023 \\
\hline $\mathrm{SCC} \mathrm{d} / \mathrm{CS} \mathrm{t}$ & $(17,44)$ & 0061 & $\mathrm{SCC} d / \mathrm{CCH} b$ & $(17,36)$ & -0013 \\
\hline $\mathrm{CH}_{2} \mathrm{r} / \mathrm{CH}_{3} \mathrm{t}$ & $(19,46)$ & -0005 & $\mathrm{SCC} \mathrm{d} / \mathrm{SC} \mathrm{t}$ & $(17,44)$ & -0017 \\
\hline $\mathrm{CH}_{2} \mathrm{tw} / \mathrm{SS} \mathrm{t}$ & $(21,42)$ & -0042 & $\mathrm{SCC} \mathrm{d} / \mathrm{CH}_{3} \mathrm{t}$ & $(17,46)$ & 0020 \\
\hline $\mathrm{CH}_{2} \mathrm{tw} / \mathrm{CH}_{3} \mathrm{t}$ & $(21,45)$ & -0006 & $\mathrm{CH}_{2} \mathrm{tw} / \mathrm{CH}_{3} \mathrm{t}$ & $(21,45)$ & -0011 \\
\hline $\mathrm{CCH} \mathrm{b/SS} \mathrm{t}$ & $(24,42)$ & 0028 & $\mathrm{CCH} b / \mathrm{SS} \mathrm{t}$ & $(23,42)$ & -0020 \\
\hline $\mathrm{CCH} \mathrm{b} / \mathrm{CH}_{3} \mathrm{t}$ & $(24,45)$ & -0014 & $\mathrm{HCH} \mathrm{b/HCH} \mathrm{b}$ & $(26,39)$ & 0004 \\
\hline $\mathrm{SC} \mathrm{t} / \mathrm{CH}_{3} \mathrm{t}$ & $(43,46)$ & -0008 & $\mathrm{SC} t / \mathrm{CH}_{3} \mathrm{t}$ & $(43,46)$ & 0004 \\
\hline
\end{tabular}

${ }^{\text {a }}$ Force constants that can be obtained by the $C_{2}$ symmetry operation are not listed in the table $b_{s}=$ stretch, $b=$ bend, $w=$ wag, $t w=$ twist, $r=$ rock, $t=$ torsion, $d=$ deformation ( see symmetry coordinates of Table 1)

ing it leads to the retention of more force constants The force constants of this simplified force field for $\mathrm{C}_{2} \mathrm{H}_{5} \mathrm{SSC}_{2} \mathrm{H}_{5}$ are listed in Table 2, the force constants which can be obtained by the $C_{2}$ symmetry operation are not listed Because of the stronger intramolecular interactions in the $\mathrm{CGC}$ and $\mathrm{G}^{\prime} \mathrm{GG}^{\prime}$ conformers than in the other four symmetric conformers, the interaction force constants between the two ethyl groups were larger in these two conformers and more force constants were retained for $C=0001$, these are listed separately For convenience, if a force constant remained in any one of the other four symmetric conformers by this criterion, we tabulated it for all six conformers

\section{SOME COMMENTS ON THE APPLICATION OF THIS FORCE FIELD}

It is necessary to keep in mind that this force field was obtained using the ab initio optımızed geometry To mınımıze any errors associated with different geometries, it is therefore necessary to use the ab initio geometry, as listed in Table 1 of our previous paper [8], when this force field is incorporated in a normal coordinate calculation The force constants for an unsymmetric disulfide bridge can be obtained in a manner similar to that described previously [8]

For most disulfide groups, $\tau(\mathrm{SS})$ is found in the range $75^{\circ}-105^{\circ}$ Our calculations indicate that the SS bond length in $\mathrm{C}_{2} \mathrm{H}_{5} \mathrm{SSC}_{2} \mathrm{H}_{5}$ varies with $\tau(\mathrm{SS})$ in a manner similar to that in $\mathrm{CH}_{3} \mathrm{SSCH}_{3}$ Therefore, to obtain more accurate 
results, the SS stretch force constant, $f(\mathrm{SS})$, can be modified according to $\tau$ (SS), using the same relationship as in $\mathrm{CH}_{3} \mathrm{SSCH}_{3}$ [9] If $\tau$ (SS) changes by $15^{\circ}$ from the optimal calculated value for the conformer (see Table 2 of our previous paper [8]), then $f(\mathrm{SS})$ should be corrected by $-10 \%$ from the value given in Table 2 of this paper, for a $30^{\circ}$ change the correction should be $-30 \%$ The CS stretch force constant does not change much with $\tau$ (SS), and therefore no correction is necessary

To calculate the normal modes of peptide molecules containıng the disulfide bridge, this scaled ab initio force field would have to be combined (at present) with empirical force fields for the peptide chain [11] The determination of the force constants in the junction between the disulfide group and the peptide chain may not be so straightforward This is because of the significantly different bases of the two force fields the ab initio, derived from the potential energy surface, has many more force constants than the empirical, which aims to reproduce the observed frequencies with as small a force constant set as possible This can make the determination of the force constants in the junction region somewhat arbitrary Another complication is that the ab initio force field is canonic [12], whereas the empirical force field is generally not If the latter is transformed to a canonic force field, the junction force constants can be initially taken as the average of the two values

\section{NORMAL COORDINATE CALCULATION FOR DIISOBUTYL DISULFIDE}

In an initial model to simulate the disulfide bridge in proteins, two $\mathrm{H}$ atoms on each side of the bridge in $\mathrm{C}_{2} \mathrm{H}_{5} \mathrm{SSC}_{2} \mathrm{H}_{5}$ were replaced by masses equal to carbon atoms This model is very similar to that used by Kuptsov and Trofimov [6] Our calculations on this model indicate that $\nu$ (CS) for any $\tau(\mathrm{CS})$ is always lower than $670 \mathrm{~cm}^{-1}$, which agrees with the result of Kuptsov and Trofimov [6] However, this is not consistent with the experimental data [2], which show that $\nu$ (CS) for dissobutyl disulfide is at 710 or $745 \mathrm{~cm}^{-1}$ if any methyl $\mathrm{C}$ atom is trans to an $\mathrm{S}$ atom This difficulty is resolved if we use the complete structure of $\left(\mathrm{CH}_{3}\right)_{2} \mathrm{CHCH}_{2} \mathrm{SSCH}_{2} \mathrm{CH}\left(\mathrm{CH}_{3}\right)_{2}$, e if we add three $\mathrm{H}$ atoms to every terminal $\mathrm{C}$ atom in the above model The $\mathrm{H}$ atoms are indispensable for obtaining the proper $\nu(\mathrm{CS})$ in the calculation, and the simplification of replacing the $\mathrm{CH}_{3}$ group by a single $\mathrm{C}$ atom is not a satisfactory approximation

In these calculations the force field for the disulfide bridge portion was taken from our scaled ab initio force field for $\mathrm{C}_{2} \mathrm{H}_{5} \mathrm{SSC}_{2} \mathrm{H}_{5}$ [8] and that for the terminal methyl groups was taken from Snyder's force field for paraffins [13] In the junction regions between these two, the average values of the force constants from these two force fields were used The geometric parameters of $\mathrm{C}_{2} \mathrm{H}_{5} \mathrm{SSC}_{2} \mathrm{H}_{5}$ [8] were used for the disulfide group and standard geometric parameters [13] were used for the isobutyl group The calculated $\nu$ (CS) values 
are shown in Fig. 2 This figure shows that when an $\mathrm{S}$ atom is trans to an $\mathrm{H}$ atom (1 e. gauche to two methyl $\mathrm{C}$ atoms), $\nu(\mathrm{CS})$ is predicted between 662 and $719 \mathrm{~cm}^{-1}$, which is similar to the result of Kuptsov and Trofimov [6]. However, when an $\mathrm{S}$ atom is trans to a methyl $\mathrm{C}$ atom, $\nu(\mathrm{CS})$ is predicted between 704 and $755 \mathrm{~cm}^{-1}$, which was not obtained by Kuptsov and Trofimov Figure 2 also shows the specific dependence of $\nu(\mathrm{CS})$ on $\tau(\mathrm{CS}) . \nu(\mathrm{CS})$ increases as $\tau(\mathrm{CS})$ increases. Previous studies have shown that $\tau(\mathrm{CS})$ is usually found at about $68^{\circ}$ (gauche) or $180^{\circ}$ (trans) From Fig 2, this leads to $\nu(\mathrm{CS})$ values of

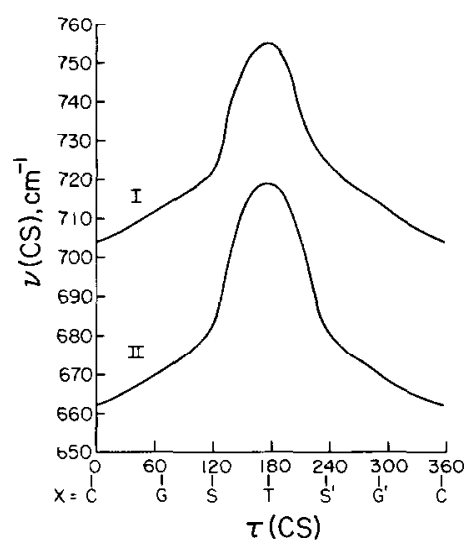

Fig 2 Dependence of $\nu(\mathrm{CS})$, the CS stretch frequency, on $\tau(\mathrm{CS})$, the CS dihedral angle, for GXG (I) and --GXT (II) $\left(\mathrm{CH}_{3}\right)_{2} \mathrm{CHCH}_{2} \mathrm{SSCH}_{2} \mathrm{CH}\left(\mathrm{CH}_{3}\right)_{2}$ The central $\mathrm{G}$ refers to $\tau$ (SS) and the terminal $\mathrm{G}$ and $\mathrm{T}$ to $\tau(\mathrm{CC})$, the HCCS dihedral angle

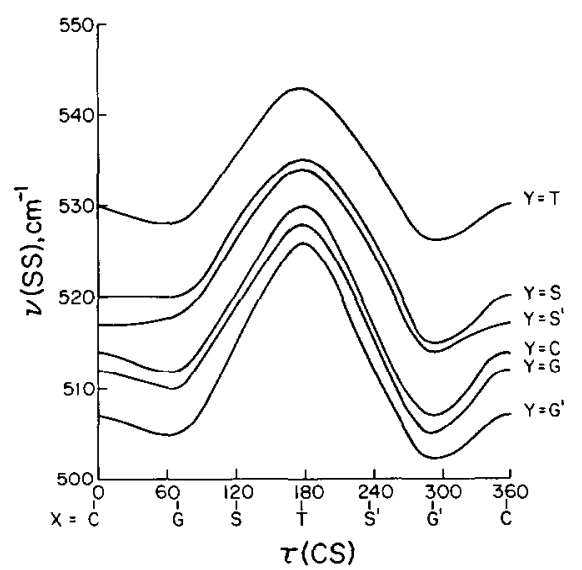

Fig 3 Dependence of $\nu$ (SS), the SS stretch frequency, on $\tau(\mathrm{CS})$, the CS dihedral angle, for GXGYG $\left(\mathrm{CH}_{3}\right)_{2} \mathrm{CHCH}_{2} \mathrm{SSCH}_{2} \mathrm{CH}\left(\mathrm{CH}_{3}\right)_{2}$ The G, X, G, Y and G in GXGYG refer to $\tau$ (HCCS), $\tau(\mathrm{CCSS}), \tau(\mathrm{CSSC}), \tau(\mathrm{SSCC})$ and $\tau(\mathrm{SCCH})$, respectively 
about $671,713 \mathrm{~cm}^{-1}$ (gauche) or about $719,755 \mathrm{~cm}^{-1}$ (trans), which are consistent with the observed values of Sugeta et al [2], $\left(666,710\right.$ and $\left.745 \mathrm{~cm}^{-1}\right)$. However, our calculations also show that the observed frequency, $710 \mathrm{~cm}^{-1}$, arises not only from the conformation with a methyl $\mathrm{C}$ atom trans to an $\mathrm{S}$ atom, as predicted by Sugeta et al. [2], but also from the conformation with two methyl $\mathrm{C}$ atoms gauche to an $\mathrm{S}$ atom, provided that $\tau(\mathrm{CS})$ is about $180^{\circ}$

The correlation of $\nu$ (SS) of $\left(\mathrm{CH}_{3}\right)_{2} \mathrm{CHCH}_{2} \mathrm{SSCH}_{2} \mathrm{CH}\left(\mathrm{CH}_{3}\right)_{2}$ with $\tau(\mathrm{CS})$ is much more complicated and cannot be shown in a single figure In Figs 3, 4

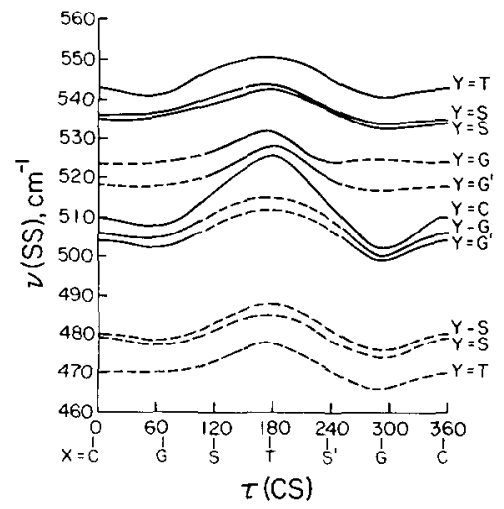

Fig 4 Dependence of $\nu(\mathrm{SS})$, the SS stretch frequency, on $\tau(\mathrm{CS})$, the CS dihedral angle, for GXGYT $\left(\mathrm{CH}_{3}\right)_{2} \mathrm{CHCH}_{2} \mathrm{SSCH}_{2} \mathrm{CH}\left(\mathrm{CH}_{3}\right)_{2}$ The G, X, G, Y and T in GXGYT refer to $\tau$ (HCCS), $\tau(\mathrm{CCSS}), \tau(\mathrm{CSSC}), \tau(\mathrm{SSCC})$ and $\tau(\mathrm{SCCH})$, respectively When $\nu(\mathrm{SS})$ makes significant contributions to two normal modes, we have indicated the frequencies containing the larger (-) and smaller (-.--) contributions to the potential energy distribution

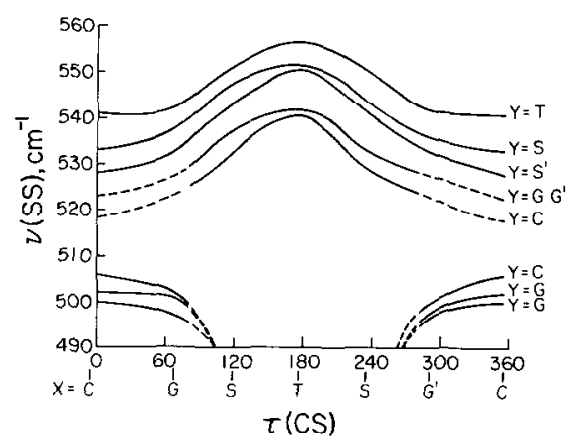

Fig 5 Dependence of $\nu$ (SS), the SS stretch frequency, on $\tau(\mathrm{CS})$, the CS dihedral angle, for TXGYT $\left(\mathrm{CH}_{3}\right)_{2} \mathrm{CHCH}_{2} \mathrm{SSCH}_{2} \mathrm{CH}\left(\mathrm{CH}_{3}\right)_{2}$, The T, X, G, Y and $\mathrm{T}$ in TXGYT refer to $\tau(\mathrm{HCCS})$, $\tau$ (CCSS), $\tau$ (CSSC), $\tau$ (SSCC) and $\tau(\mathrm{SCCH})$, respectively When $\nu$ (SS) makes significant contributions to two normal modes, we have indicated the frequencies containing the larger (-) and smaller (-.--) contributions to the potential energy distribution 
and 5 we show $\nu$ (SS) for GXGYG, GXGYT and TXGYT, respectıvely, where the terminal $\mathrm{G}$ and $\mathrm{T}$ refer to $\tau(\mathrm{HCCS})$ and $\tau(\mathrm{SCCH})$ and the $\mathrm{X}$ and $\mathrm{Y}$ refer to $\tau$ (CCSS) and $\tau$ (SSCC), respectively By comparing with the observed $\tau$ (SS) of $\left(\mathrm{CH}_{3}\right)_{2} \mathrm{CHCH}_{2} \mathrm{SSCH}_{2} \mathrm{CH}\left(\mathrm{CH}_{3}\right)_{2}, 512$ and $525 \mathrm{~cm}^{-1}$ [2], it is found that the-GGG-conformation of this molecule may exist However, its is clear from Figs 3, 4 and 5 that other structures could also account for the $512 \mathrm{~cm}^{-1}$ band Several structures could also account for the $525 \mathrm{~cm}^{-1}$ band

\section{A SIMPLE WAY TO IDENTIFY LOCAL $C_{2}$ SYMMETRY OF THE DISULFIDE BRIDGE}

By analyzing the calculated results for $\mathrm{CH}_{3} \mathrm{SSCH}_{3}, \mathrm{C}_{2} \mathrm{H}_{5} \mathrm{SSC}_{2} \mathrm{H}_{5}$ and $\left(\mathrm{CH}_{3}\right)_{2} \mathrm{CHCH}_{2} \mathrm{SSCH}_{2} \mathrm{CH}\left(\mathrm{CH}_{3}\right)_{2}$ we have found that the symmetric $\nu(\mathrm{CS})$ is
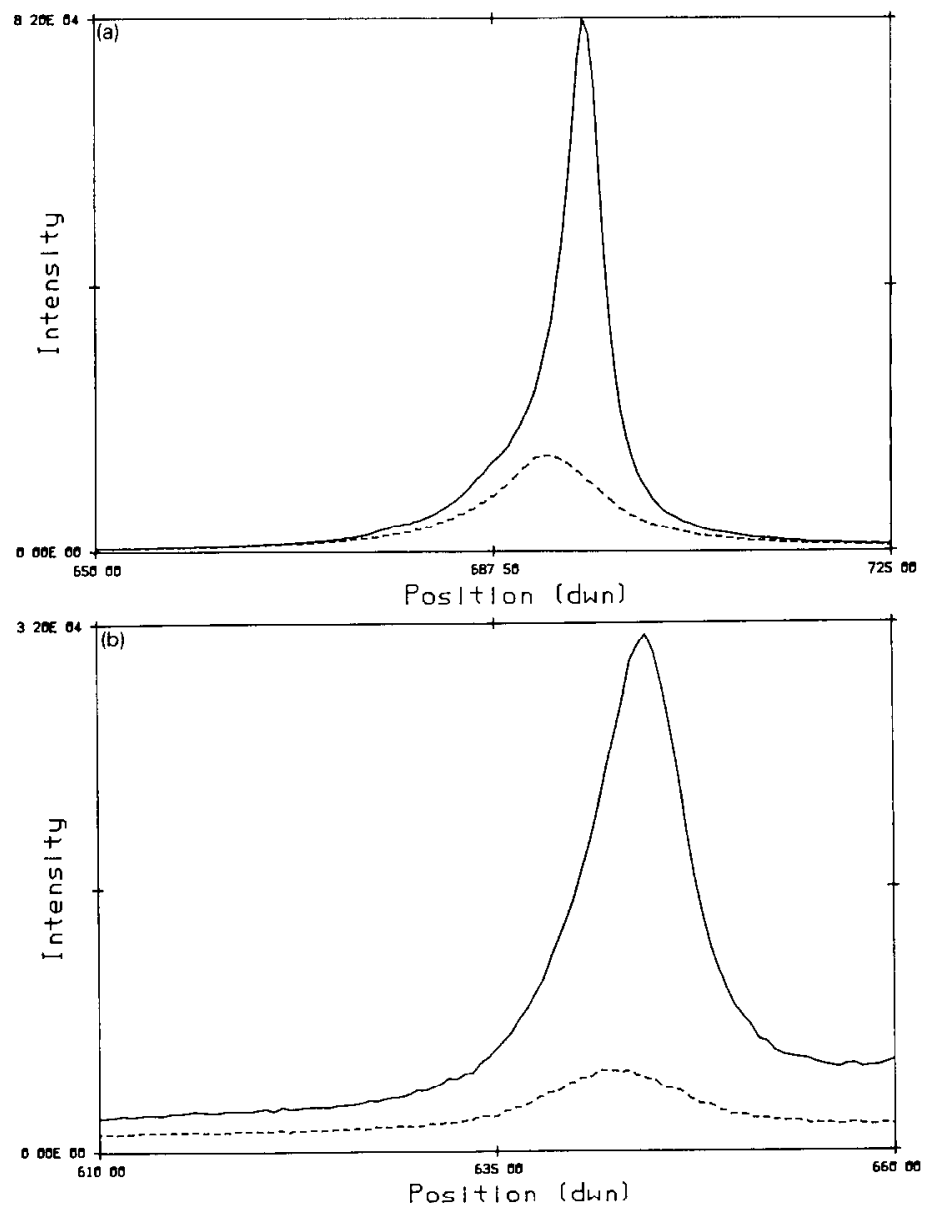

Fig 6 Raman spectra of the CS stretch bands of (a) $\mathrm{CH}_{3} \mathrm{SSCH}_{3}$ and (b) $\mathrm{C}_{2} \mathrm{H}_{5} \mathrm{SSC}_{2} \mathrm{H}_{5}$-, parallel spectrum, ----, perpendicular spectrum 
always higher than the antısymmetric $\nu$ (CS) by $5-20 \mathrm{~cm}^{-1}$ for any symmetric conformation of these molecules For these conformations, the symmetric $\nu(\mathrm{CS})$ interacts with $\nu(\mathrm{SS})$, resulting in an increase in frequency of the former and a decrease in the latter. The antisymmetric $\nu(\mathrm{CS})$ has a different symmetry from $\nu(\mathrm{SS})$ and therefore there is no interaction between them

As a result of this, a local $C_{2}$ symmetry of the disulfide bridge can be recognized easily from a Raman polarization experiment. If $\nu(\mathrm{CS})$ in the parallel orientation is a few wavenumbers higher than the frequency in the perpendicular orientation, the disulfide bridge can be identified as having a local $C_{2}$ symmetry environment We carried out such Raman polarization experıments for $\mathrm{CH}_{3} \mathrm{SSCH}_{3}$ and $\mathrm{C}_{2} \mathrm{H}_{5} \mathrm{SSC}_{2} \mathrm{H}_{5}$ The frequency shifts between the different polarization orientations for these two molecules were 35 and $20 \mathrm{~cm}^{-1}$, respectively (see Fig 6) These values are smaller than those obtained from our calculations, partly because of the overlap of the symmetric and antisymmetric $\nu$ (CS) bands ( $1 \mathrm{C}_{2} \mathrm{H}_{5} \mathrm{SSC}_{2} \mathrm{H}_{5}$, also because of the overlap with one of the $\nu(\mathrm{CS})$ bands of the GGT conformer)

\section{CONCLUSIONS}

By elıminating about $75 \%$ of the force constants in our full scaled ab initio force field for $\mathrm{C}_{2} \mathrm{H}_{5} \mathrm{SSC}_{2} \mathrm{H}_{5}$ [8], we have produced a force field that still reproduces the observed frequencies very well This force field will make the application of normal mode analysis to the study of the disulfide bridge in proteins more manageable

As a model for this disulfide bridge, we have performed complete normal mode analyses of the possible conformers of $\left(\mathrm{CH}_{3}\right)_{2} \mathrm{CHCH}_{2} \mathrm{SSCH}_{2} \mathrm{CH}\left(\mathrm{CH}_{3}\right)_{2}$ Additional correlations have been demonstrated beyond those obtained previously $[6,10]$

Our theoretical and experimental studies show that a local $C_{2}$ symmetry of the disulfide bridge can be revealed from Raman polarization measurements on the $\nu(\mathrm{CS})$ modes since the symmetric $\nu(\mathrm{CS})$ is expected to be higher than the antisymmetric $\nu(\mathrm{CS})$, polarized spectra of such structures show a higher frequency intense band in parallel polarization and a lower frequency weak band in perpendicular polarization

\section{ACKNOWLEDGEMENT}

This research was supported by the Monsanto Company, St Louss, MO, and by NSF grants DMB-8816756 and DMR-8806975 


\section{REFERENCES}

1 R C Lord and N-T Yu, J Mol Biol, 50 (1970) 509

2 H Sugeta, A Go and T Myazawa, Chem Lett, (1972) 83, Bull Chem Soc Jpn, 46 (1973) 3407

3 H Brunner and M IIolz, Biochim Biophys Acta, 379 (1975) 408

4 H E Van Wart and H A Scheraga, J Phys Chem, 80 (1976) 1812, 1823

5 T Takamatsu, I Harada and K Hayashı, Biochım Biophys Acta, 622 (1980) 189

6 A H Kuptsov and V I Trofimov, J Biomol Struct Dyn, 3 (1985) 185

7 H E Van Wart and H A Scheraga, Proc Natl Acad Sc1 USA, 83 (1986) 3064

8 W Zhao and S Krımm, J Mol Struct, 224 (1990) 7

9 W Zhao, J Bandekar and S Krımm, J Am Chem Soc, 110 (1988) 6891

10 H Sugeta, Spectrochim Acta, part A, 31 (1975) 1729

11 S Krimm and J Bandekar, Adv Protein Chem, 38 (1986) 181

12 K Kuczera and R Czerminskı, J Mol Struct, 105 (1983) 269

13 R G Snyder, J Chem Phys, 47 (1967) 1316 